\title{
FEM ANALYSIS OF PROPPANT STICKING IN ROCK CRACKS
}

\author{
M. KWIETNIEWSKI ${ }^{1}$, D. MIEDZIŃSKA ${ }^{2}$, T. NIEZGODA ${ }^{3}$
}

\begin{abstract}
The problem of effective gas extraction from Polish shale rocks is an interesting research subject for scientists. A properly selected proppant, which protects cracks from closing during the fracturing process, inestimably contributes to an increase of extraction. Grains of proppant are transported along with a fracturing medium to reach the deepest regions of the crack. The proper support of the crack provides an easy flow of gas, therefore it is important in terms of extraction efficiency. This paper shows the interactions of a proppant grain with the crack surface in shale rock. FEM analysis was conducted to observe the stress region, which is generated as a result of pressing the grain into the crack surface. A model of a sphere which was pressed into the rock model with constant velocity was applied. The received results of stress depend on material properties and a range of proppant grain pressing.
\end{abstract}

Keywords: FEM analysis, proppant, shale rock, crack, fracturing, contact, slave, master, embedment, Newmark

\footnotetext{
${ }^{1}$ MSc., Eng., Military University of Technology, Faculty of Mechanical Engineering, Department of Mechanics and Applied Computer Science, Gen. Witolda Urbanowicza Street 2, 00-908 Warszawa 2, 00-908 Warsaw, Poland, e-mail: michal.kwietniewski@wat.edu.pl

${ }^{2}$ PhD., Eng., Military University of Technology, Faculty of Mechanical Engineering, Department of Mechanics and Applied Computer Science, Gen. Witolda Urbanowicza Street 2, 00-908 Warsaw, Poland, e-mail: danuta.miedzinska@wat.edu.pl

${ }^{3}$ Prof., DSc., PhD., Eng., Military University of Technology, Faculty of Mechanical Engineering, Department of Mechanics and Applied Computer Science, Gen. Witolda Urbanowicza Street 2, 00-908 Warsaw, Poland, e-mail: tadeusz.niezgoda@wat.edu.pl
} 


\section{INTRODUCTION}

Currently, to meet a growing demand for fossil fuels, extraction of hydrocarbons is realized from unconventional sources, such as shale rock. For a more effective extraction of shale gas it is essential to create cracks during the fracturing process to ensure a free flow of gas released from the rock structure. Over at least few years Polish territory has been the object of widespread research aimed at elaborating a coast-effective technology for shale gas production. Polish shale rocks are different from those of North America both in physical and chemical terms. They are also deployed at different depths. The distinct structure of the rocks sets new challenges for downhole drilling. Fracturing processes take place in a slightly different way, therefore it is necessary to develop a new extraction technology. One of the most important aspects of this research is the analysis of the behaviour of rocks under fracturing pressure. A mechanism of initialization and propagation of a crack in the rock and an optimal method for crack support after the fracturing process should be taken into consideration. Those functions are performed by proppant which is transported to a deposit with a fracturing medium. The grains, mostly ceramic and with high hardness, are intended to wedge in the rock to maximise the crack opening. Ceramic proppants are formed from ceramic slips through mechanical granulation. Then, they are subjected to heat treatment to obtain high strength. However, for very high internal stresses of rock mass, the proppants are pressed into the rock. This phenomenon causes minimisation of a crack cross-section and, in extreme cases, can lead to a complete closing of the fracture $[2,5]$.

\section{GEOMETRY MODELS}

For the needs of FEM the geometric model shown in Fig. 1 has been developed. It was assumed that the model of the rock is a quarter of a cylinder with a crack with a $1 \mathrm{~mm}$ radius in the central part. The model of shale rock, with an $8 \mathrm{~mm}$ radius and a length of $10 \mathrm{~mm}$, was generated. Similarly to the rock model, a grain of proppant was assumed as a quarter of a sphere [2].

Discretization of the model was carried out in LS-PrePost software using HEX-8 elements. Hex-8 element is a linear solid and fully integrable (integration points $2 \times 2 \times 2$ ) element of general purpose [3]. The created model consisted of 29554 elements and 60696 nodes. 


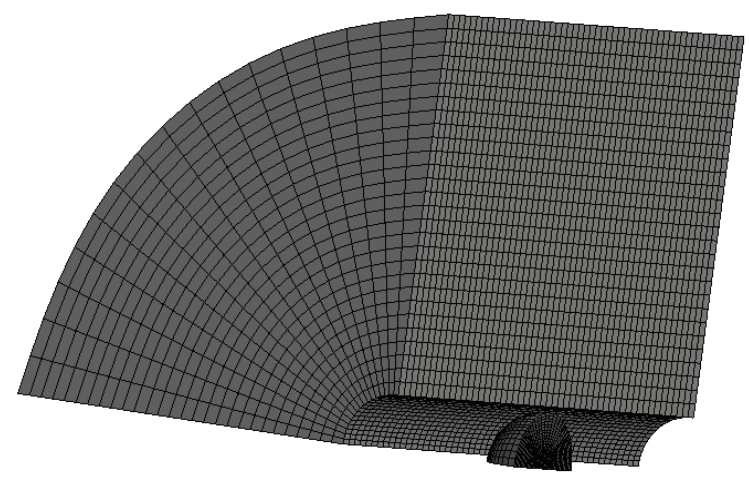

Fig. 1. Geometrical model with a finite element mesh.

\section{BOUNDARY CONDITIONS}

The aim of the analysis is to observe stress in the shale rock during the pressing of the grain of proppant into crack surfaces. A cylindrical surface of the rock model was fixed in translation degrees of freedom on each node. Fig. 2 shows the surface with fixed nodes.

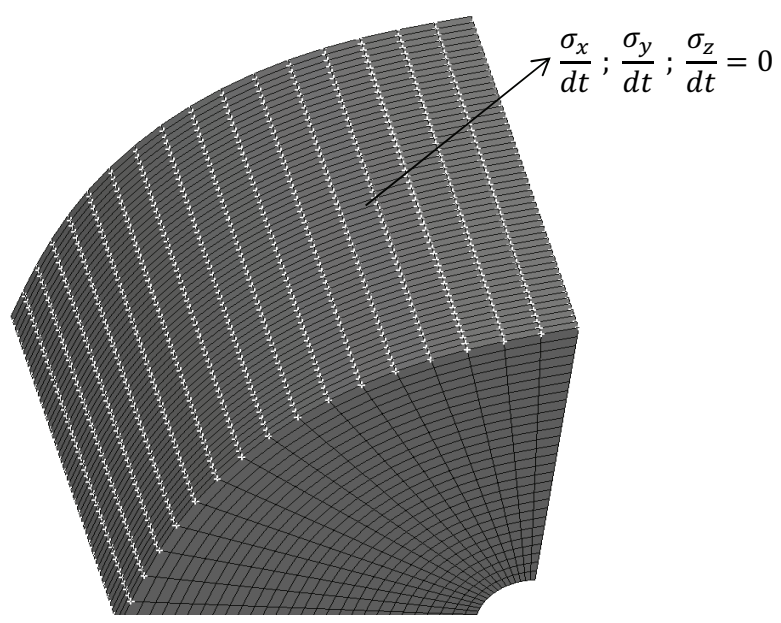

Fig. 2. Surface with fixed nodes.

Additionally, taking into account the fact that the calculations are based on the fourth part of the model, appropriate symmetry conditions were applied to the rest of the surfaces. The process 
of pressing a proppant grain was induced by the applied displacement into the rock model, which was increasing during analysis, as shown in Fig. 3. A vector of applied displacement is a resultant of horizontal and vertical direction and value of motion directed into the rock. Vectors of displacement are shown in Fig. 4.

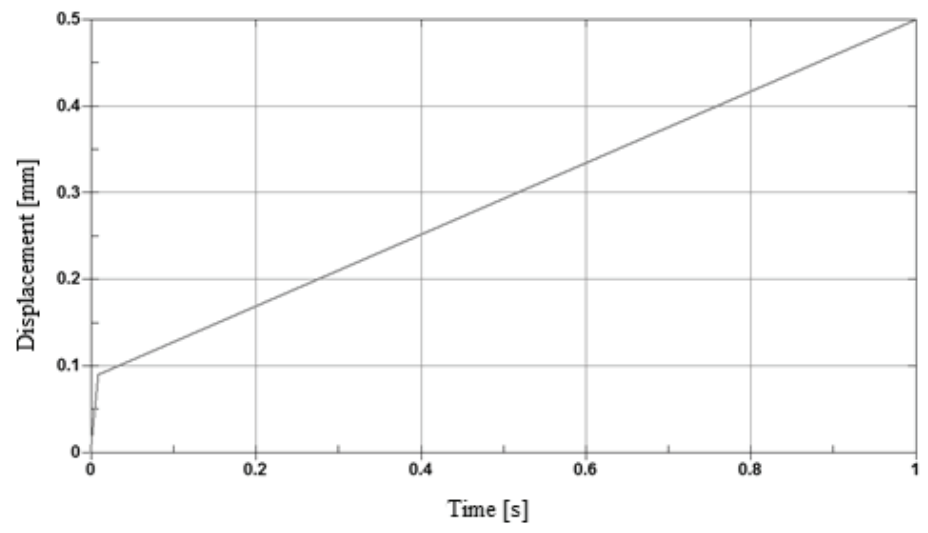

Fig. 3. Initial displacement of a proppant grain.

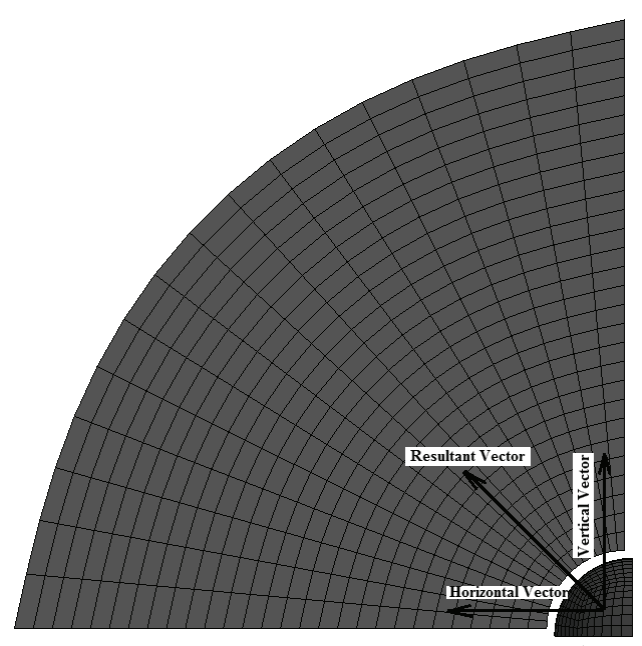

Fig. 4. Direction of applied displacement vector. 
To provide proper interaction between the contacting models, a grain of proppant was moved away from the surface of the crack by $0.1 \mathrm{~mm}$ at the initial stage of analysis. AUTOMATIC_SURFACE_TO_SURFACE was applied as a contact type in this analysis [3]; this contact type is recommended in crash simulations. An automatic detection of contact allows us to check penetration in both models and contact is established when the surface of one body penetrates surface of another body [6]. The scheme of this so-called Surface-to-Surface contact applied in the model is shown in Fig. 5. The location of the models could be arbitrary and cannot be provided as a model with large deformations. Surface-to-Surface contact is a major algorithm and is used often when contact areas are large and in cases where contact surfaces are known. This contact type specifically is very useful for sliding bodies, such as a block sliding on a plate [4].

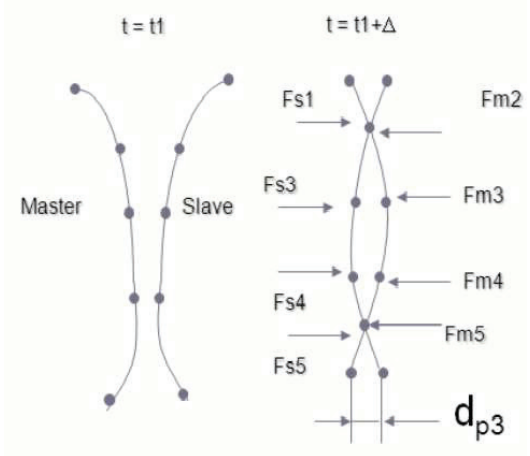

Fig. 5. Scheme of Surface to Surface contact [4].

Eq. (3.1) describing the sense of this contact type is show below [4]:

$$
F_{m 3}=f_{s} \cdot k \cdot d_{p 3}
$$

where:

$f_{s}$ - penalty scale factor,

$k$ - proportional constant,

$d_{p 3^{-}}$penetration at node 


\section{MATERIAL MODEL}

To conduct numerical calculations it was necessary to implement the rock's material properties. For shale rock, MAT_084/85-WINFRITH_CONCRETE [3] was assumed, with mechanical properties specified in Table 1. This material model is used for modelling in geomechanics, where compressing forces are usually the leading ones. Model Winfrith can generate a new binary base containing information about position, length, and direction of the crack. To create a crack database the LSDYNA execution line is modified by adding $q$, which is shown in Eq. (4.1):

$$
q=c r f
$$

where crf is the required database name. LS-PrePost can display fractures on the damaged mash. Finally, the user can see the crack displayed on the model.

For a model of proppant RIGID a completely undeformable material was applied [3]. A significant difference of the hardness of proppant compared to the shale rock was taken into consideration [1].

Table 1. Mechanical properties of shale rock [own study]

\begin{tabular}{|c|c|}
\hline Parameters & Value \\
\hline Young [MPa] & 4000 \\
\hline Poisson [-] & 0.25 \\
\hline Density [kg/m $\left.{ }^{3}\right]$ & 2200 \\
\hline Tensile strength $[\mathrm{MPa}]$ & 1 \\
\hline Compressive strength $[\mathrm{MPa}]$ & 40 \\
\hline
\end{tabular}

\section{METHOD OF CALCULATIONS}

One of the most popular methods with a wide range of applications in engineering analyses is the Finite Element Method (FEM). It is an approximation method in which a result is estimated based on partial differential equations which constitute a mathematical model of a process or a physical condition. The essence of this method is a split of a real model (continuous model) into small size finite elements which are joints with nodes. An implicit algorithm is used for static analyses where the final state is an equilibrium or when simulating the phenomenon of a several-second-long 
duration. Implicit schemes use a system of derived equations based on the results of the current and future steps. In LS-Dyna solver one of the available implicit algorithms is the Newmark method. In this method, it is possible to search out results by many algorithms, where user-defined parameters $\gamma$ and $\beta$ can be changed. An algorithm named 'steady value of acceleration' $\left(\gamma=\frac{1}{2}, \beta=\frac{1}{4}\right)$ is applied by default in LS-Dyna. This algorithm provides a high accuracy of calculation and, opposite of the central difference method, stability does not depend on the timestep (absolutely stable). The Newmark method is described in Eq. (5.1):

$$
\begin{gathered}
M \ddot{x}_{t+\Delta t}+C \dot{x}_{t+\Delta t}+K x_{t+\Delta t}=F_{t+\Delta t} \\
x_{t+\Delta t}=\tilde{x}_{t+\Delta t}+\Delta t^{2} \beta \ddot{x}_{t+\Delta t} \\
\dot{x}_{t+\Delta t}=\tilde{x}_{t+\Delta t}+\Delta t \gamma \ddot{x}_{t+\Delta t} \\
\tilde{x}_{t+\Delta t}=x_{t}+\Delta t \dot{x}_{t}+\left(\frac{\Delta t^{2}}{2}\right)(1-2 \beta) \ddot{x}_{t} \\
\tilde{\dot{x}}_{t+\Delta t}=\dot{x}_{t}+\Delta t(1-\gamma) \ddot{x}_{t} \\
\ddot{x}_{t+\Delta t}=0
\end{gathered}
$$

where:

$M$-mass matrix, $C$ - damping matrix, $K$-stiffness matrix, $F$-load matrix, $\ddot{x}$-acceleration vector, , $\dot{x}$-velocity vector, $x$ - coordinate vector, $\gamma$ - user-defined parameters, $\beta$ - user-defined parameters.

\section{RESULTS OF ANALYSIS}

An FE simulation was executed in LS-Dyna solver. The analysis was conducted using an implicit algorithm in static conditions. A quadrant model which clearly shows the state of stress and enables a significant shortening of computing time was adopted. The results of the analysis showed that the model of the rock could have been even smaller, as the stress resulting from pressing concerned only a small area. The maximum value of reduced Huber-Misses-Hencky stress (56 MPa) was obtained, concentrating on the line of rock and proppant contact, which is shown in Fig. 6. Moreover, the maximum resultant displacement of the nodes directly interacting with the pressed proppant at a level of $0.06 \mathrm{~mm}$ was observed and is shown in Fig. 7. 


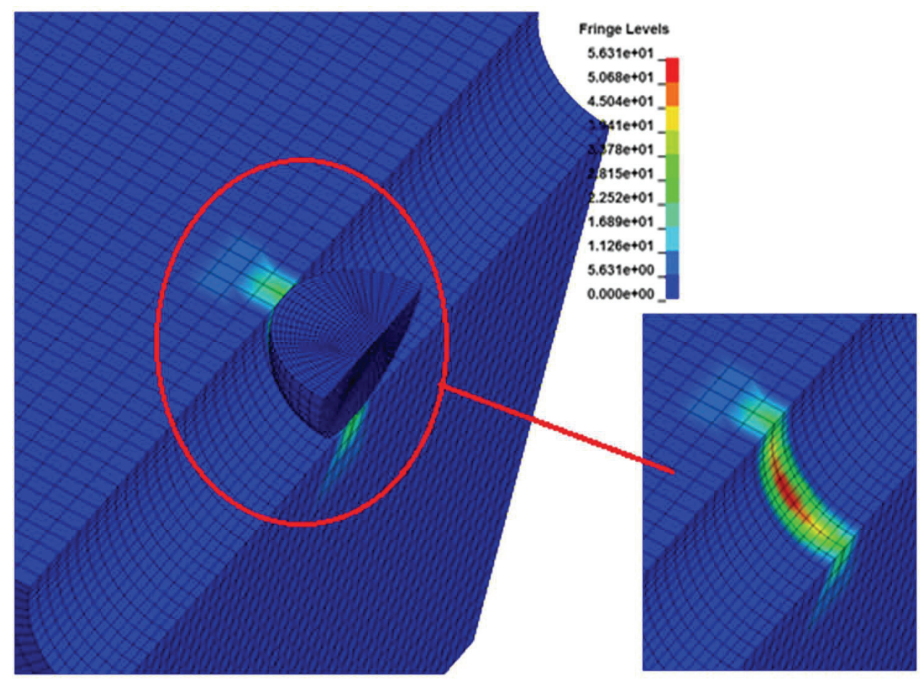

Fig. 6. Map of HMH stress on the rock model.

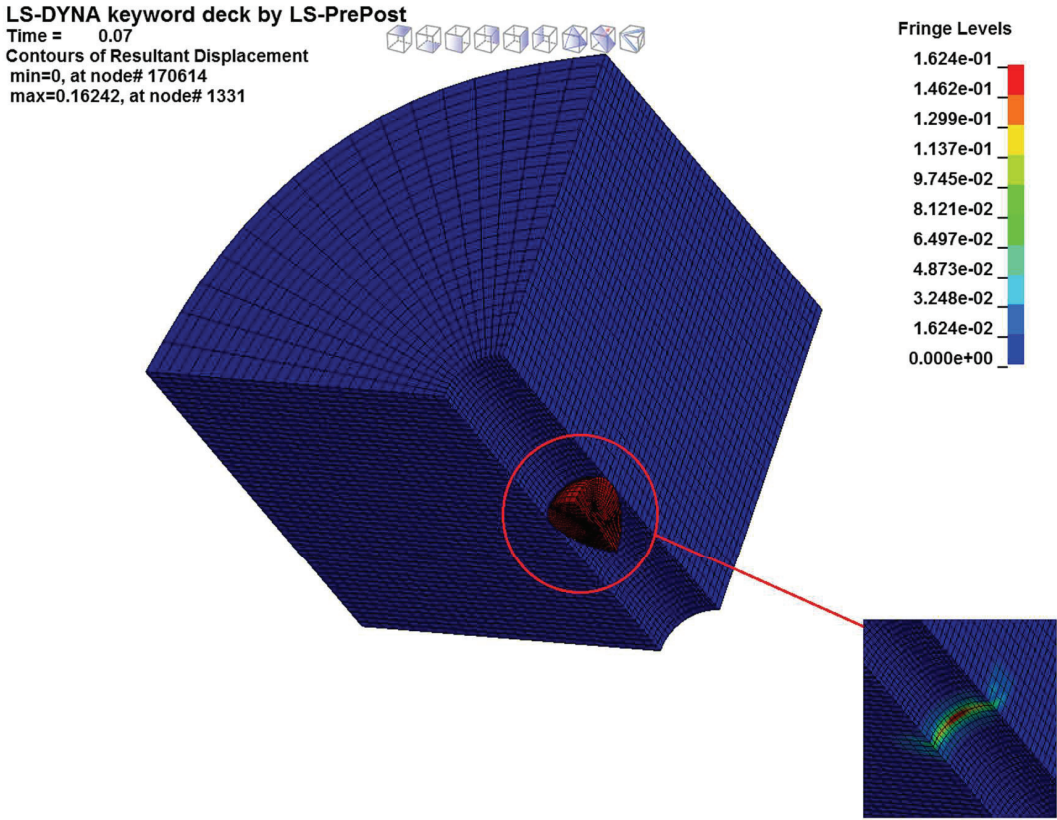

Fig. 7. Map of nodes resultant displacement. 


\section{CONCLUSIONS}

In this paper, numerical calculations were conducted and for the applied material models and boundary conditions the process of grain pressing into a rock crack was observed. After conducting analysis the following conclusions can be drawn:

1) Stress was not observed on the rigid model of a grain, as was expected.

2) Relatively low stress leads to material damage which is caused by the application of a low value of shale rock strength.

3) The area of stress influence caused by the pressing of the proppant is relatively small.

4) The maximum value of the generated stress is greater than the rock's compression strength, which may result from the occurrence of a complex state of stress around the contact area of the rock and proppant.

\section{ACKNOWLEDGEMENTS}

The paper is supported by grant No BG2/DIOX4SHELL/14 titled "Development of guidelines for design of innovative technology of shale gas recovery with the use of liquid $\mathrm{CO}_{2}$ on the base of numerical and experimental research -DIOX4SHELL", supported by the National Centre for Research and Development (NCBR) in years 2014-2017.

\section{REFERENCES}

1 A. Nowakowski, J. Nurkowski, Z. Lizak., “Zależność wyniku testu ściśliwości próbki węgla od rodzaju płynu porowego", Prace Instytutu Mechaniki Górotworu PAN, Vol 14, No. 1-4, , p. 53-62, 2012

2 J. Walaszczyk, L. Florkowska, "Komputerowa symulacja stanu naprężenia w sąsiedztwie wyrobiska górniczego z uwzględnieniem przepływu gazu”. Górnictwo i geoinżynieria. Year 34. Sheet 2. 2010.

3 LS-dyna keyword user's manual volume I LS-dyna r8.0, Livermore Software Technology Corporation (LSTC), 03/23/15 (r:6319).

4 M.L.J Suman, "Contact in LS-Dyna", M.S. Ramaiah School of Advanced Studies, Bengaluru (pdf file, access 17.03.2017)

5 T. Majcherczyk, P. Małkowski, Z. Niedbalski, “Ocena przemieszczeń górotworu wokół wyrobiska korytarzowego z wykorzystaniem parametrów empirycznych”, Akademia Górniczo-Hutnicza Kraków, Wydział Górnictwa i Geoinżynierii, Mat. Symp. p. 249-260.

6 www.dynasupport.com (access 27.11.2016) 


\section{LIST OF FIGURES AND TABLES:}

Fig. 1. Geometrical model with mesh

Rys. 1. Model geometryczny z siatką

Fig. 2. Surface with fixed nodes

Rys. 2. Powierzchnia z utwierdzonymi węzłami

Fig. 3 Initial displacement of proppant grain

Rys. 3. Krzywa inicjująca przemieszczenie

Fig. 4. Map of stress on rock model

Rys. 4. Mapa naprężeń w modelu skały

Fig. 5. Map of nodes displacement

Rys. 5. Mapa przemieszczeń węzłów

Table 1. Mechanical properties of shale rock

Tabela 1. Mechaniczne właściwości skały łupkowej 


\section{ANALIZA MES WCISKANIA PROPPANTU W PĘKNIĘCIE SKALNE}

Keywords: analiza MES, proppant, łupek, pęknięcie, szczelinowanie, kontakt, Newmark

\section{STRESZCZENIE:}

Terytorium Polski od kilku lat jest obiektem wzmożonych badań mających na celu opracowanie opłacalnej technologii wydobycia gazu z łupków. Polskie skały łupkowe różnią się pod względem fizycznym i chemicznym od tych występujących w Ameryce Północnej, są rozlokowane również na innej głębokości. Inna budowa skały stawia zatem nowe wyzwania dla wiertnictwa otworowego. Procesy szczelinowania zachodzą w nieco inny sposób, zatem konieczne jest opracowanie nowej technologii wydobycia. Jednym z ważniejszych aspektów tych badań jest dokładna analiza zachowania się skały obciążonej ciśnieniem szczelinowania. Do rozważenia jest tu mechanizm powstawania i propagacji pęknięcia oraz optymalny sposób podparcia szczeliny po zabiegu szczelinowania. Tę funkcję mają pełnić proppanty, które dostają się do złoża wraz z czynnikiem szczelinującym. Ziarenka, najczęściej ceramiczne o dużej twardości mają za zadanie zaklinować się w skale, aby utworzyć maksymalne rozwarcie szczeliny. Oczywiście, przy ogromnych naprężeniach wewnętrznych górotworu następuje wgniatanie ziaren w powierzchnię skały, co powoduję zmniejszenie przekroju poprzecznego szczeliny, a w skrajnych przypadkach może prowadzić do całkowitego zamknięcia szczeliny

Do analizy MES opracowano model geometryczny. Przyjęto, że model skały to czwarta część walca ze szczeliną w środkowej części o promieniu $1 \mathrm{~mm}$. Wygenerowano model skały łupkowej o promień $8 \mathrm{~mm}$ oraz długości $10 \mathrm{~mm}$. Analogicznie do modelu skały, przyjęto ziarenko proppantu jako 1/4 kuli. Dyskretyzację modelu przeprowadzono w oprogramowaniu LS - PrePost za pomocą elementów ośmiowęzłowych. Utworzony model składa się z 29554 elementów oraz 60696 węzłów.

Celem analizy jest obserwacja zachowania łupka w wyniku wciskania ziarenka proppantu. Utwierdzenie zostało nałożone na powierzchnie cylindryczną łupka odbierając wszystkie stopnie swobody w każdym z węzłów. Dodatkowo, uwzględniając fakt, że do obliczeń przyjęto czwartą część modelu, nałożono na ściany odpowiednie warunki symetrii. Proces wciskania ziarenka proppantu został wywołany za pomocą przyłożonego przemieszczenia, które narastało w trakcie analizy. Dla zapewnienia prawidłowego oddziaływania między kontaktującymi się modelami, ziarno proppantu w początkowej fazie odsunięto od szczeliny o $0,1 \mathrm{~mm}$. Analizę przeprowadzono w warunkach statycznych. Otrzymano naprężenia zredukowane według hipotezy Hubera-Missesa-Hencky’ego o maksymalnej wartości 56 MPa, które skupiają się na linii kontaktu proppantu z modelem skały, co zaprezentowano na rys. 5. Ponadto zaobserwowane maksymalne odkształcenie węzłów bezpośrednio reagujących z wciskanym proppantem na poziomie $0.06 \mathrm{~mm}$.

Dla przyjętych modeli materiałowych oraz warunków brzegowych, zaobserwowano proces wciskania ziarenka proppantu. Po przeprowadzeniu analizy można wyciągnąć następujące wnioski:

1) Stosunkowo niewielkie naprężenia prowadzą do uszkodzenia materiału.

2) Obszar wpływu naprężeń, wywołanych wciskaniem proppantu jest niewielki.

3) Maksymalna wartość uzyskanych naprężeń jest wyższa niż wytrzymałość skały na ściskanie. Może to wynikać z faktu występowania złożonego stanu naprężenia w obrębie kontaktu skały z proppantem. 